\title{
Synchronous primary gastric triple-hit high-grade B- cell lymphoma and gastric adenocarcinoma: endoscopic and pathological findings
}

\author{
Claudia Covelli (i) , ${ }^{1}$ Paola Parente, ${ }^{1}$ Domenico Trombetta, ${ }^{2}$ Paolo Graziano ${ }^{1}$
}

'Pathology Unit, IRCCS Ospedale Casa Sollievo della Sofferenza, San Giovanni Rotondo, Foggia, Italy 'Laboratory of Oncology, IRCCS Ospedale Casa Sollievo della Sofferenza, San Giovanni Rotondo, Foggia, Italy

Correspondence to Dr Claudia Covelli; cla.covelli85@gmail.com

Accepted 24 June 2021
Check for updates

(C) BMJ Publishing Group Limited 2021. No commercial re-use. See rights and permissions. Published by BMJ.

To cite: Covelli C, Parente $P$, Trombetta $\mathrm{D}$, et al. BMJ Case Rep 2021;14:e244643. doi:10.1136/bcr-2021244643

\section{DESCRIPTION}

A 82-year-old man was admitted to our institution with a 2-month history of fatigue and loss of appetite. Laboratory studies revealed anaemia, with haemoglobin level of $7.9 \mathrm{~g} / \mathrm{dL}$ and a red cell count of $2.9 \times 10^{12} / \mathrm{L}$; the white cell count was normal. Upper endoscopy showed two discrete gastric lesions: one in the antrum, ulcerated, $5 \mathrm{~cm}$ in diameter; the other in the fundus, polypoid in shape, $2 \mathrm{~cm}$ in diameter (figure $1 \mathrm{~A}, \mathrm{~B}$ ), separated by intervening uninvolved mucosa. Biopsies demonstrated an adenocarcinoma in the antrum, and a diffuse infiltrate of large, monomorphous B-cells suspicious for lymphoma in the fundus, respectively.

Positron emission tomography/CT scan did not reveal any extragastric site of pathological ${ }^{18} \mathrm{~F}$-fluorodeoxyglucose uptake. Therefore, a total gastrectomy with D2 lymphadenectomy was performed.

On microscopic examination (figure 1C,D), the antral lesion was a moderately differentiated, intestinal type adenocarcinoma, with regional nodal metastases. According to the American Joint Committee on Cancer Classification, ${ }^{1}$ the pathological stage was IIIA (pT4a N1).

In regards to the fundic lesion, histology showed a diffuse infiltrate of large lymphoid cells in the oxyntic mucosa, extending into the perivisceral fat and involving one perigastric lymph node. The cells were immunoreactive for CD20, CD79a, bcl-2 (>50\%), IRF4/MUM1, c-myc (>40\%) and

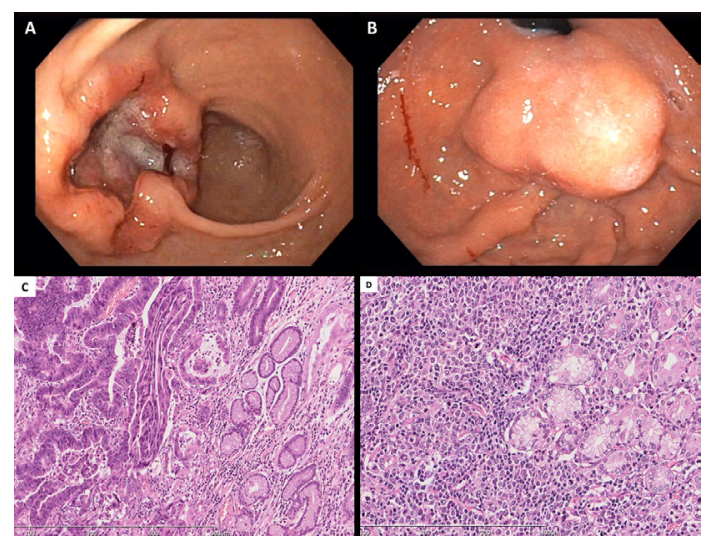

Figure 1 Upper endoscopy showed (A) an excavated mass in the antrum and (B) a polypoid lesion located in the fundus. Microscopic examination documented (C) an intestinal type adenocarcinoma in the antral mucosa $(H \& E, 10 x)$ and $(D)$ a diffuse infiltrate of large, atypical lymphoid cells in the oxyntic mucosa (H\&E,10x). negative for CD3, CD10, bcl-6 and LMP (latent membrane protein of Epstein-Barr virus (EBV)). The Ki-67 proliferation index was 90\%. In situ hybridisation for EBV-encoded small RNA (EBER) was performed, and it showed a negative result in the neoplastic cells. No component of low-grade lymphoma was identified.

Rearrangements of MYC, BCL2 and BCL6 were evaluated by fluorescence in situ hybridisation (FISH), using specific probes (namely, Vysis LSI MYC Dual Color Break Apart Rearrangement Probe; Vysis LSI BCL2 Dual Color Break Apart FISH Probe; Vysis LSI BCL6 Dual Color Break Apart Rearrangement Probe; Abbott, Chicago, Illinois), with the analyses of 50 nonoverlapping nuclei. Rearrangements of MYC, BCL2 and BCL6 (figure 2) were detected in the neoplastic cells,

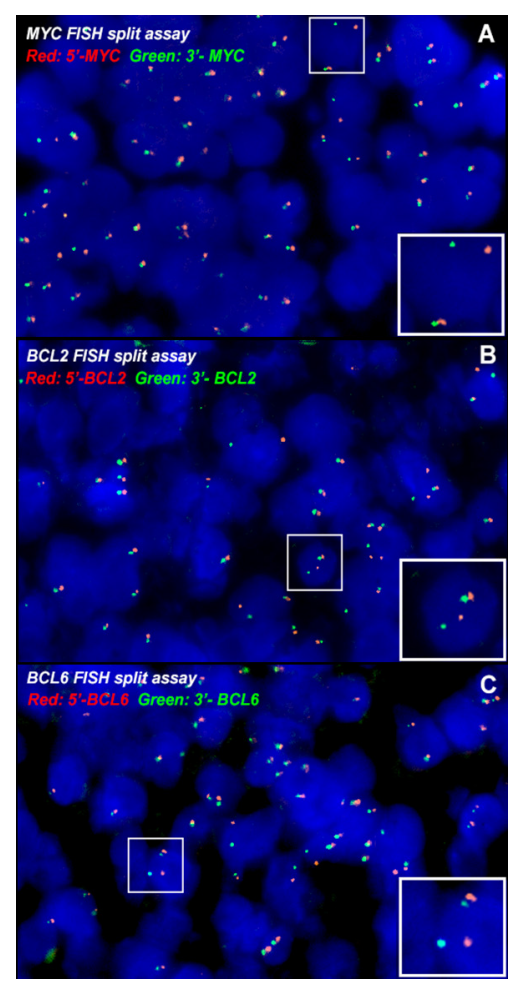

Figure 2 Break-apart fluorescence in situ hybridisation (FISH) for MYC (A), BCL2 (B) and BCL6 (C) genes. The green probe and the red probe hybridise to the regions $3^{\prime}$ and $5^{\prime}$ of each gene, respectively. The white squares show the separation of the red and green probe signals, indicating a chromosomal rearrangement. BCL2: B-cell lymphoma 2; BCL6: B-cell lymphoma 6; MYC, MYC protooncogene. 
with a percentage of rearranged nuclei of $26 \%, 30 \%$ and $34 \%$, respectively.

Consequently, a diagnosis of triple-hit high-grade B-cell lymphoma was rendered, and it was confirmed to be primitive of the stomach according to Dawson's criteria. ${ }^{23}$

After surgery, the patient was discharged symptom free. He received adjuvant chemotherapy with six cycles of capecitabine and rituximab and is currently in good clinical conditions, with no recurrence.

The occurrence of synchronous primary malignancies with different hystogenesis in the same organ is extremely unusual. Although adenocarcinoma and lymphoma are the two most common gastric malignancies, they rarely occur simultaneously. Moreover, the majority of these patients is diagnosed with extranodal marginal zone lymphoma of mucosa-associated lymphoid tissue. ${ }^{4}$ Since the new category of double/triple-hit high-grade B-cell lymphoma was introduced in the revised edition of the WHO classification, ${ }^{5}$ this is the first case of synchronous gastric triple-hit high-grade B-cell lymphoma and gastric adenocarcinoma reported in the literature.

Given the rarity of this event, our case emphasises the importance to biopsy adequately all endoscopically visible lesions, in order to provide the best therapeutic management for this exceptional occurrence.

Acknowledgements We thank Dr Rossella Cubisino for providing endoscopic images and Dr Francesca Sanguedolce for providing EBER-ISH stain.

Contributors CC collected and analysed the data, drafted and revised the initial manuscript. PP and DT drafted and revised the initial manuscript. PG critically revised the manuscript for important intellectual content. All the authors read and approved the final manuscript.

Funding The authors have not declared a specific grant for this research from any funding agency in the public, commercial or not-for-profit sectors.

Competing interests None declared.

\section{Learning points}

The synchronous occurrence of gastric adenocarcinoma and gastric lymphoma is extremely rare, and primary gastric high-grade B-cell lymphoma with MYC, BCL2 and BCL6 rearrangements has never been described in association with gastric adenocarcinoma.

- The importance of becoming proficient in the diagnosis of this exceptional association is related to the different therapeutic approaches in the treatment of lymphoma and cancer, nonsurgical for the former and surgical for the latter. Therefore, special attention should be paid to the possibility of the simultaneous occurrence of gastric adenocarcinoma and lymphoma, in order to evaluate the most effective therapy for these patients.

Patient consent for publication Obtained

Provenance and peer review Not commissioned; externally peer reviewed.

ORCID iD

Claudia Covelli http://orcid.org/0000-0001-7158-059X

\section{REFERENCES}

1 Brierley JD, Gospodarwicz MK, Wittekind C. TNM classification of malignant tumours 8th ed. Oxford: Wiley Blackwell, 2017.

2 Dawson IM, Cornes JS, Morson BC. Primary malignant lymphoid tumours of the intestinal tract. Report of 37 cases with a study of factors influencing prognosis. $\mathrm{Br}$ J Surg 1961:49:80-9.

3 Pizzi M, Sabattini E, Parente P, et al. Gastrointestinal lymphoproliferative lesions: a practical diagnostic approach. Pathologica 2020;112:227-47.

4 Hamaloglu E, Topaloglu S, Ozdemir A, et al. Synchronous and metachronous occurrence of gastric adenocarcinoma and gastric lymphoma: a review of the literature. World J Gastroenterol 2006:12:3564-74.

5 Swerdlow SH, Campo E, Harris NL. Who classification of tumours of haematopoietic and lymphoid tissues, revised. 4th ed. Lyon, France: IARC, 2017.

Copyright 2021 BMJ Publishing Group. All rights reserved. For permission to reuse any of this content visit

https://www.bmj.com/company/products-services/rights-and-licensing/permissions/

BMJ Case Report Fellows may re-use this article for personal use and teaching without any further permission.

Become a Fellow of BMJ Case Reports today and you can:

- Submit as many cases as you like

- Enjoy fast sympathetic peer review and rapid publication of accepted articles

- Access all the published articles

Re-use any of the published material for personal use and teaching without further permission

Customer Service

If you have any further queries about your subscription, please contact our customer services team on +44 (0) 2071111105 or via email at support@bmj.com.

Visit casereports.bmj.com for more articles like this and to become a Fellow 